\title{
RADIOLOGICAL PRESENTATION OF COVID-19 PNEUMONIA
}

\author{
Aleksandra Đurić-Stefanović1,2 \\ ${ }^{1}$ Centar za radiologiju i MR, Univerzitetski klinički centar Srbije, \\ Beograd, Srbija \\ ${ }^{2}$ Medicinski fakultet, Univerzitet u Beogradu, Srbija \\ ${ }^{1}$ Center for Radiology and MR Imaging, University Clinical Center of \\ Serbia, Belgrade Serbia \\ 2 Faculty of Medicine, University of Belgrade, Serbia
}

\section{SAŽETAK}

Intrersticijumska pneumonija je dominantna manifestacija oboljenja KOVID-19. Ciljradajeda seprikažu:spektartipičnih radiološkihnalaza(CT-kompjuterizovana tomografija i radiografija) KOVID-19 pneumonije, različite tehnike (T pregleda, tipovi i evolucija inflamatornih promena u plućima, kriterijumi za procenu verovatnoce KOVID-19 pneumonije u odnosu na druge intersticijumske pneumonije, i principi bodovanja (scoring) za definiciju obima KOVID-19 pneumonije, na osnovu CT nalaza i radiografije. Standardni protokol CT pregleda je nativni CT pregled grudnog koša, a zbog visoke senzitivnosti niskodoznih CT protokola za detekciju promena u plućima, ova tehnika snimanja je postala široko zastupljena u radiološkoj praksi tokom pandemije KOVID-19. Obostrane, multiple, kružne ili slivene zone denziteta "mlečnog stakla”, dominantno lokalizovane subpleuralno, periferno i posteriorno, obično najobimnije u donjim režnjevima, predstavljaju tipičnu CT prezentaciju KOVID-19 pneumonije. U kasnijem stadijumu se mogu razviti i konsolidacije. Na rendgenskom snimku pluća mogu da se vide: homogeno smanjena transparencija u lateralnim plućnim poljima, kružna i nepravilna oblačasta zasenčenja i slivena mrljasta zasenčenja, obično najobimnija bazalno i lateralno. Za procenu verovatnoće KOVID-19 pneumonije, na osnovu kriterijuma tipičnog/atipičnog CT nalaza, koriste se RSNA i CO-RADS kriterijumi. Prema CT karakteristikama promena u plućima i vremenskoj dinamici njihove prezentacije, definisana su četiri stadijuma KOVID-19 pneumonije: rani, progresivni, stadijum konsolidacije i stadijum organizacije. Za procenu obima i težine pneumonije pomoću (T-a, predloženi su različiti sistemi bodovanja, od kojih je najšire prihvaćen (T severity scoring system, koji se zasniva na vizuelnoj semikvantitativnoj proceni procentualne zahvacenosti parenhima svakog od pet lobusa pluća zapaljenskim promenama, na skali od $1(<5 \%)$ do $5(>75 \%)$, tako da maksimalni skor može da iznosi 25.

Ključne reči: KOVID-19 pneumonija, kompjuterizovana tomografija, radiografija pluća

Autor za korespondenciju:

Aleksandra Đurić-Stefanović

Centar za radiologiju i MR, Univerzitetski klinički centar Srbije

Odeljenje digestivne radiologije, Klinika za digestivnu hirurgiju (Prva

hirurška klinika)

Koste Todorovića 6, 11129 Beograd, Srbija

E-mail: aleksandra.djuricstefanovic@gmail.com

Primljeno - Received: July 14, 2021; Revidirano - Revised: August 14, 2021;

\begin{abstract}
Interstitial pneumonia is the main manifestation of the COVID-19 disease. The aim of this paper is to present the spectrum of typical radiological findings (CT computed tomography, and radiographic) in COVID-19 pneumonia, the different CT examination techniques, the types and evolution of inflammatory lesions in the lungs, the criteria for assessing the probability of COVID-19 pneumonia in comparison to other types of interstitial pneumonia, and the scoring systems for determining the extent of COVID-19 pneumonia, based on CT findings and radiography. The standard CT examination protocol is a native CT examination of the chest, and, due to high sensitivity of low-dose CT protocols for detecting lung lesions, this imaging technique has become widely used in radiological practice during the COVID-19 pandemic. Bilateral, multiple, round or confluent zones of ground-glass density, predominantly localized subpleurally, peripherally and posteriorly, usually most extensive in the lower lobes, represent a typical CT presentation of COVID-19 pneumonia. Consolidations may develop at a later stage. A chest X-ray shows homogeneously reduced transparency in the lateral pulmonary fields, circular and irregular cloudlike shadows, and confluent patchy shadows, usually most extensive basally and laterally. RSNA and CO-RADS criteria are used to assess the probability of COVID-19 pneumonia, based on the criteria of a typical/atypical CT finding. Four stages of COVID-19 pneumonia have been defined, based on the dynamics of inflammatory lung lesion presentation: early, progressive, the phase of consolidation and the phase of organization. To assess the extent and severity of pneumonia, various scoring systems have been proposed, the most widely accepted one being the CT severity scoring system, based on visual semiquantitative assessment of the percentage of lung parenchyma inflammation lesions involvement of each of the five lobes, on a scale of $1(<5 \%)$ to $5(>75 \%)$, whereby the maximum score can be 25 .
\end{abstract}

Keywords: COVID-19 pneumonia, computed tomography, chest X-ray

Corresponding author:

Aleksandra Đurić-Stefanović, PhD

Center for Radiology and MR Imaging, University Clinical Center of Serbia

Department of Digestive Radiology, Hospital for Digestive Surgery (First Surgical Hospital)

6 Koste Todorovića Street, 11129 Beograd, Serbia

E-mail: aleksandra.djuricstefanovic@gmail.com

Prihvaćeno • Accepted: August 23, 2021; Online first: September 30, 2021. 


\section{UVOD}

Prvi radovi o kliničkim i radiološkim manifestacijama kod obolelih od infekcije izazvane novim korona virusom, koji je, nešto kasnije, zvanično nazvan SARSKoV-2, objavljeni su online, 24. januara 2020. godine $\mathrm{u}$ časopisima Lancet i New England Journal of Medicine [1-3]. Prema zvaničnim podacima Svetske zdravstvene organizacije, od decembra 2019. godine, kada je epidemija izbila u gradu Vuhanu, u Kini, i ubrzo se proširila po celom svetu, tokom pandemije oboljenja KOVID-19 (engl. Corona Virus Disease 2019), koja je zvanično proglašena 11. marta 2020. godine, do početka juna 2021. godine, potvrđeno je preko 174 miliona zaraženih, i preko 3,7 miliona umrlih ljudi.' Prema zvaničnim podacima Ministarstva zdravlja Republike Srbije, od prvog zvanično potvrđenog slučaja oboljenja KOVID-19 u Srbiji, 6. marta 2020. godine, do 11 . juna 2021. godine, potvrđeno je 714.634 zaraženih i 6.951 umrlih. $^{2}$

Intrersticijumska pneumonija je dominantna manifestacija oboljenja KOVID-19, slično kao i kod njegovih "prethodnika" iz iste grupe izazivača: SARS (engl. severe acute respiratory syndrome) i MERS (engl. Middle East respiratory syndrome) $[1,2]$. Glavni simptomi KOVID-19 infekcije su povišena temperatura, malaksalost i kašalj. Mogu da budu prisutni i glavobolja, bolovi u mišićima, gušobolja, gubitak osećaja mirisa i ukusa, proliv i dr, a u krvnoj slici se može pojaviti leukopenija sa limfopenijom $[1,2]$. Nekoliko dana od početka bolesti, može da se javi otežano disanje, tj. osećaj „kratkog daha", što je simptom koji ukazuje na respiratornu insuficijenciju uzrokovanu KOVID-19 pneumonijom [1,2].

Kod većine pacijenata zaraženih novim korona virusom, kompjuterizovanom tomografijom (CT) se vizualizuju promene u parenhimu pluća karakteristične za intersticijumsku pneumoniju virusne etiologije, ali sa nekim osobenostima koje karakterišu KOVID-19 pneumoniju $[1,2,4,5]$. Obostrane, multiple, kružne ili slivene zone denziteta "mlečnog stakla", dominantno lokalizovane subpleuralno/periferno i posteriorno, obično najobimnije u donjim režnjevima, predstavljaju tipičnu CT prezentaciju KOVID-19 pneumonije [1-5]. U kasnijem stadijumu se mogu razviti i konsolidacije [1-5]. lako je u brojnim studijama pokazano da je kompjuterizovana tomografija senzitivnija od $P C R$ testa u detekciji KOVID-19 infekcije $[6,7]$, kao i da u značajnom procentu detektuje promene u plućima i kod asimptomatskih pacijenata [8], prema dostupnim vodičima kliničke prakse, ne preporučuje se rutinska primena CT-a kod svih pacijenata [9].

Radiografija pluća, iako znatno manje senzitivna od CT-a, naročito u ranom stadijumu i kod lakših kli-

\section{INTRODUCTION}

The first studies related to clinical and radiological manifestations present in patients suffering from the infection caused by the new corona virus, which was subsequently officially named SARS-CoV-2, were published online on January 24, 2020, in the Lancet and New England Journal of Medicine [1-3]. According to the official data issued by the World Health organization, since December 2019, when the epidemic broke out in the city of Wuhan, in China, and very quickly spread all over the world, throughout the pandemic of the COVID-19 disease (Corona Virus Disease 2019), which was officially declared on March 11, 2020, until June 2021, cases of more than 174 million infected and over 3.7 million deceased persons have been confirmed. ${ }^{1}$ According to the official data issued by the Ministry of Health of the Republic of Serbia, since the first officially confirmed case of COVID-19 in Serbia, on March 6,2020 , until June 11,2021 , cases of 714,634 infected patients and 6,951 deceased patients have been confirmed. ${ }^{2}$

Interstitial pneumonia is the dominant manifestation of the COVID-19 disease, as is the case with its 'predecessors' from the same group of pathogens: SARS (severe acute respiratory syndrome) and MERS (Middle East respiratory syndrome) [1,2]. The main symptoms of the COVID-19 infection are fever, faintness and coughing. The following may also be present: headache, pain in the muscles, a sore throat, loss of smell and taste, diarrhea, etc., while leukopenia with lymphopenia may be detected in the blood $[1,2]$. Several days after the onset of disease, labored breathing may occur, i.e., the sensation of shortness of breath, which is a symptom indicating respiratory insufficiency caused by COVID-19 pneumonia [1,2].

In most patients infected with the new corona virus, computed tomography (CT) is applied, in order to obtain an image of the changes occurring in the parenchyma of the lungs, which are characteristic of interstitial pneumonia of viral etiology, but, with certain features which characterize COVID-19 pneumonia $[1,2,4,5]$. Bilateral, multiple, circular or confluent zones of ground-glass density, which are predominantly localized subpleurally/peripherally and posteriorly, with the largest zones located in the lower lobes, represent the typical presentation of COVID-19 pneumonia [1-5]. Consolidations may also develop at a later stage [1-5]. Although numerous studies have shown that computed tomography is more sensitive in detecting the COVID-19 infection than the PCR test $[6,7]$, and that, in a significant percentage of the patients, it also detects changes in the lungs even in asymptomatic patients

\footnotetext{
$1 \mathrm{https}: / /$ covid19.who.int

2 https://covid19.rs
}

1 https://covid19.who.int

2 https://covid19.rs 

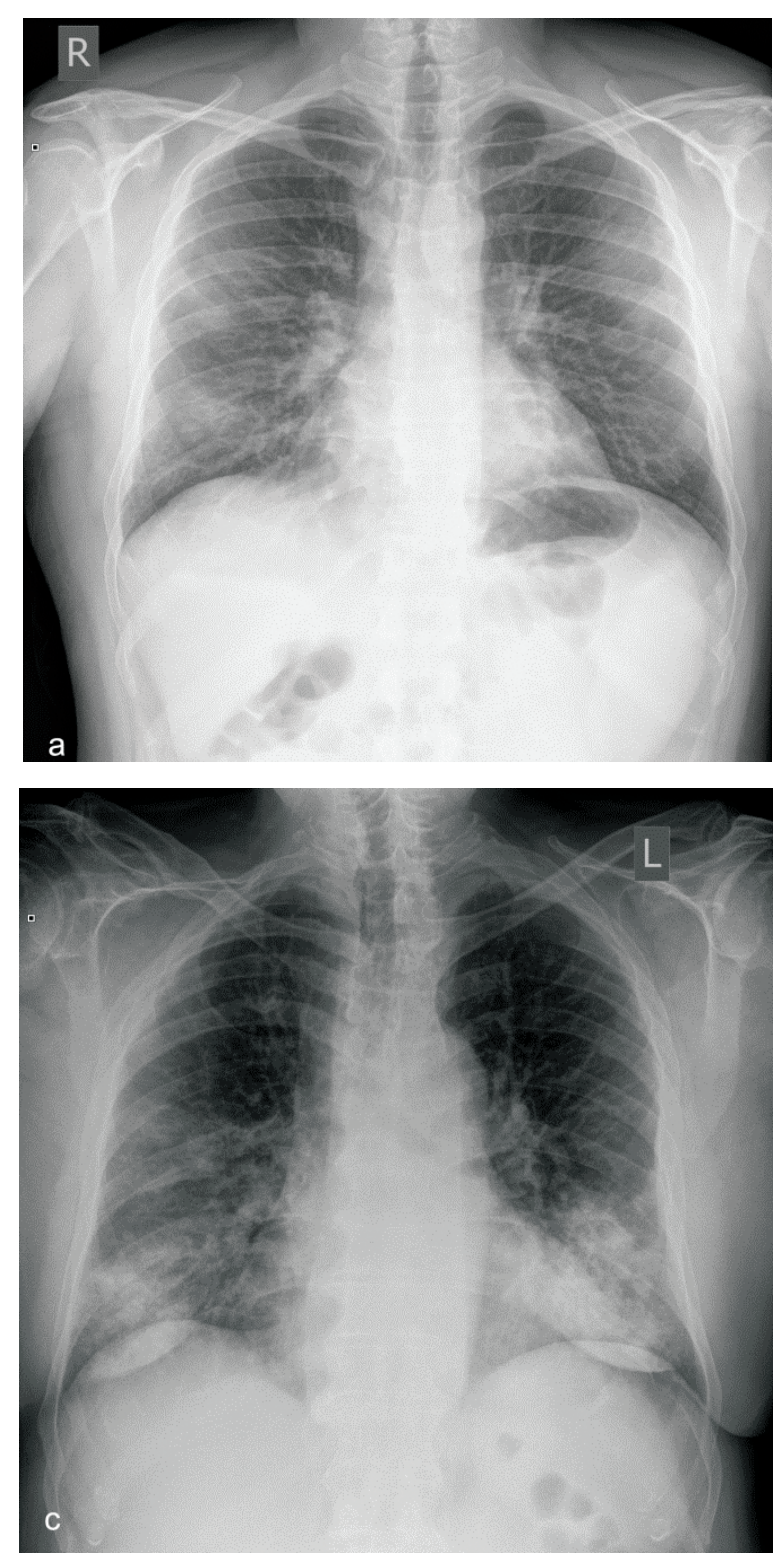

Slika 1. Radiografska prezentacija KOVID-19 pneumonije: homogeno smanjena transparencija u lateralnim plućnim poljima (periferna "velasta“ zasenčenja) (a); kružna i nepravilna oblačasta zasenčenja, obostrano (b); konfluentna mrljasta zasenčenja, obostrano bazalno, i „velasta" zasenčenja lateralno (c); obimna konfluentna mrljasta zasenčenja, bazalno i lateralno, obostrano (d)

ničkih oblika bolesti, zbog masovne dostupnosti, jednostavnijeg, kratkotrajnijeg i bezbednijeg izvođenja, kao i manje eksponencijalne doze zračenja za pacijenta, ostaje široko zastupljena u trijaži i praćenju pacijenata sa KOVID-19 oboljenjem, a metoda prvog izbora u praćenju teških i slabo pokretnih bolesnika koji su hospitalizovani u jedinicama intenzivne nege [9]. Na rendgenskom snimku pluća, mogu se videti: naglašena retikularna šara (kao najranija radiološka manifestacija), homogeno smanjena transparencija u lateralnim plućnim poljima (periferna „velasta“ zasenčenja) (Slika 1a), kružna i nepravilna oblačasta zasenčenja (Slika 1b), i konfluentna mrljasta zasenčenja, obično najobimnija bazalno i lateralno [10,11] (Slika 1c, 1d).
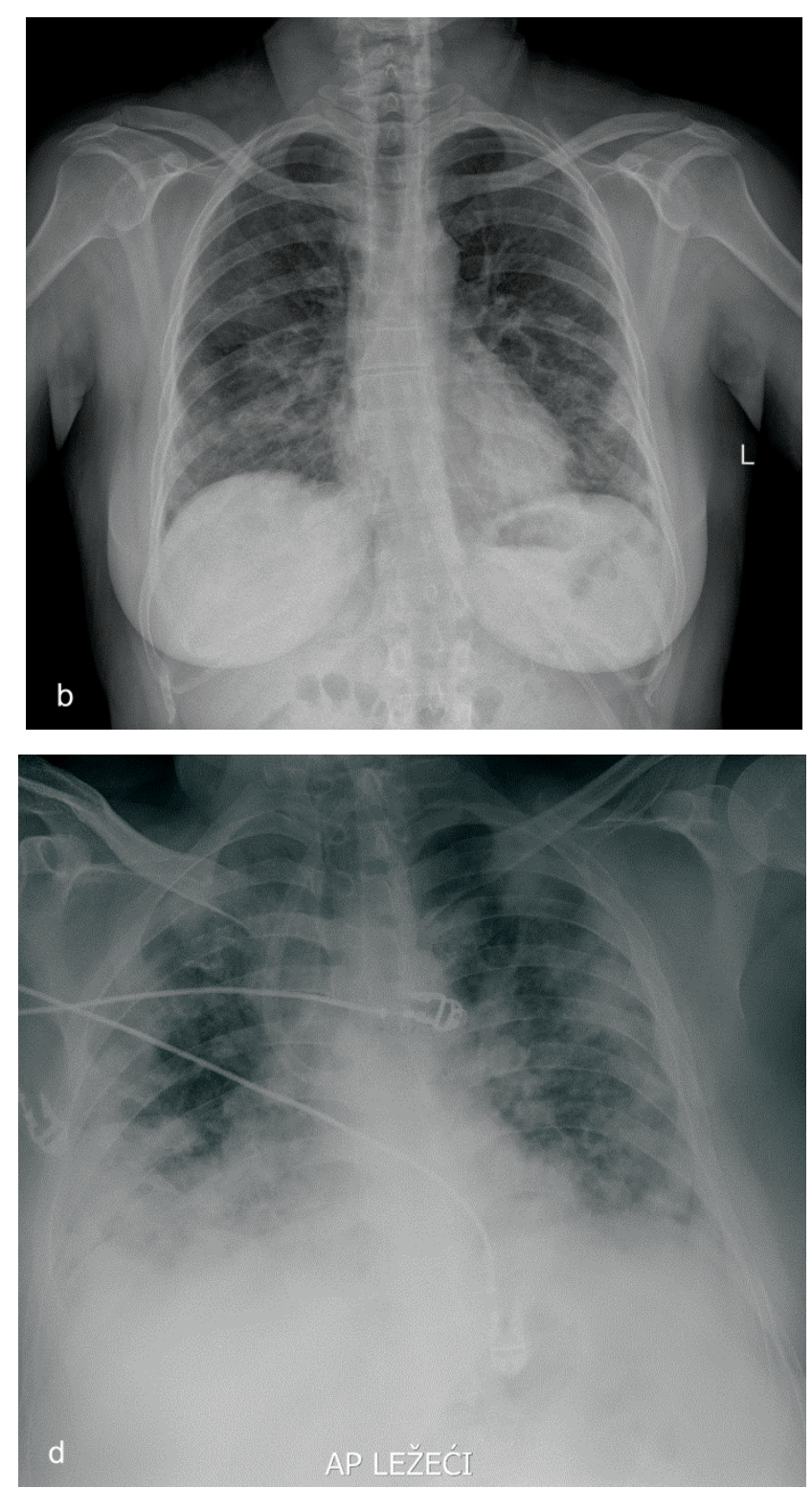

Figure 1. Radiographic presentation of COVID-19 pneumonia: homogeneously reduced transparency in lateral pulmonary fields (a); circular and irregular cloudlike shadows, bilaterally (b); confluent bilateral patchy shadows, basally, and veil-like shadows, laterally (c); extensive confluent bilateral patchy shadows, basally and laterally (d)

[8], according to available clinical practice guidelines, routine application of $\mathrm{CT}$ imaging in all patients is not recommended [9].

Chest radiography, although less sensitive than $\mathrm{CT}$, especially in the early phase and in milder clinical forms of the disease, due to wide availability, simpler, shorter and safer application, as well as a lower exponential dose of radiation for the patient, remains widely applied in triage and follow-up of COVID-19 patients, and it is the method of choice in monitoring severely ill patients and patients with low mobility who are hospitalized in intensive care units [9]. X-ray images of the lungs may show the following: a pronounced reticular pattern (as the earliest radiological manifestation), 


\section{TEHNIKA CT PREGLEDA}

Od početka epidemije u Kini, na osnovu prethodnih iskustava sa epidemijama SARS-a i MERS-a, pri čemu je ista praksa nastavljena u celom svetu, standardni protokol pregleda je tzv. nativni CT pregled grudnog koša, što podrazumeva CT pregled bez intravenskog davanja jodnog kontrasta, zbog brže, jednostavnije i bezbednije primene za osoblje i pacijente $[4,12]$. Kako je u nekoliko studija pokazana prihvatljivo visoka senzitivnost niskodoznih CT protokola, ova tehnika snimanja je postala široko zastupljena u radiološkoj praksi tokom pandemije KOVID-19 oboljenja, jer se niskodoznom tehnikom eksponencijalna doza zračenja smanjuje na manje od $1 \mathrm{mSv}$, u poređenju sa 5 - $10 \mathrm{mSv}$, koliko iznosi doza koju pacijent primi prilikom standardnog CT pregleda grudnog koša [13]. U slučajevima kliničke sumnje na plućnu emboliju, koja se sa značajnom učestalošću javlja kod obolelih od KOVID-19 pneumonije, radi se $C T$ pregled sa intravenskim davanjem jodnog kontrasta, po protokolu za pulmoangiografiju [14].

\section{TIPOVI I EVOLUCIJA LEZIJA U PLUĆIMA}

Tipovi lezija u plućima kod pacijenta sa lakšom ili srednje teškom kliničkom slikom, koji su se uspešno oporavili od KOVID-19 pneumonije, i njihova evolucija u vremenskom intervalu od početka simptoma do ozdravljenja, opisani su u radovima Pana i saradnika, koji su objavljeni online, 13. februara 2020. godine [4], a kasnije i u brojnim drugim studijama $[5,15,16]$.

Tabela 1. Evolucija KOVID-19 pneumonije, po stadijumima, prema CT prezentaciji kod pacijenata sa lakom i srednje teškom kliničkom slikom i povoljnim kliničkim ishodom [4] homogenously decreased transparency in the lateral pulmonary fields (peripheral veil-like shadows) (Figure 1a), circular and irregular cloudlike shadows (Figure $1 \mathrm{~b})$, and confluent patchy shadows, usually most extensive basally and laterally $[10,11]$ (Figures 1c, 1d).

\section{CT EXAMINATION TECHNIQUE}

Since the onset of the epidemic in China, based on the previous experiences with the SARS and MERS epidemics, with the same practice being applied in the whole world, the standard protocol for the examination is the, so called, native-phase CT examination of the thorax, which entails a CT examination without intravenous application of iodine contrast material, for the purpose of faster, simpler and safer application, both for staff and patients $[4,12]$. Due to the fact that several studies have demonstrated acceptably high sensitivity of lowdose CT protocols, this imaging technique has become widely applied in radiological practice during the COVID-19 pandemic, since low-dose technique reduces the exponential radiation dose to less than $1 \mathrm{mSv}$, as compared to $5-10 \mathrm{mSv}$, which is the level of the dose absorbed by a patient during a CT examination of the thorax [13]. In cases of clinical suspicion of pulmonary embolism, which occurs with significant frequency in COVID-19 pneumonia, CT examination with intravenous application of iodine contrast material is carried out, in keeping with the protocol for pulmoangiography [14].

Table 1. The evolution of COVID-19 pneumonia, by stages, according to CT presentation in patients with mild or moderate clinical presentation and favorable clinical outcome [4]

\begin{tabular}{|c|c|c|}
\hline Stadijum & $\begin{array}{l}\text { Prosečan vremenski period } \\
\text { od pojave simptoma }\end{array}$ & CT prezentacija \\
\hline Stage & $\begin{array}{l}\text { Average time period } \\
\text { until the onset of symptoms }\end{array}$ & CT presentation \\
\hline
\end{tabular}
1. Rani (incipijentni)
$0-4$. dana
1. Early (incipient)
Day $0-4$

Promene denziteta „mlečnog stakla“ (intersticijumski pneumonitis) - povećan denzitet u vidu „zamagljenja“ unutar kojih se razaznaju krvni sudovi (Slika 2a, 2b) Zones of ground-glass density (interstitial pneumonitis) - increased density in the form of cloudlike shadows within which blood vessels are perceptible (Figure 2a, 2b)

$\begin{array}{lc}\text { 2. Progresivni (proliferativni) } & 5-8 . \text { dana } \\ \text { 2. Progressive (proliferative) } & \text { Day } 5-8\end{array}$

Povećanje denziteta sa finom mrežom zadebljalih intralobularnih septi unutar promena (proliferacija intersticijuma), (znak „popločavanja”) (Slika 2c)

Increased density with a fine web of thickened intralobular septs within the changes (proliferation of the interstitium), ('paving-stone' sign) (Figure 2c)

Konsolidacija - povećanje denziteta tako da se ne razaznaju krvni sudovi, vidljiv vazdušni bronhogram (Slika 2d, 2e)
3. Pik (vrhunac)
9 - 13. dana
3. Peak
Day $9-13$

Consolidation - increase in density to the extent that the blood vessels are no longer visible, the air bronchogram sign is visible (Figures $2 d, 2 e$ )
4. Rezolucija (organizacija)
$\geq 14$. dana
4. Resolution (organization)
$\geq$ Day 14

Organizujuća pneumonija - linearne i trakaste promene sa zaostalom konsolidacijom (Slika 2f)

Organizing pneumonia - linear and band-like changes with residual consolidation (Figure 2f) 

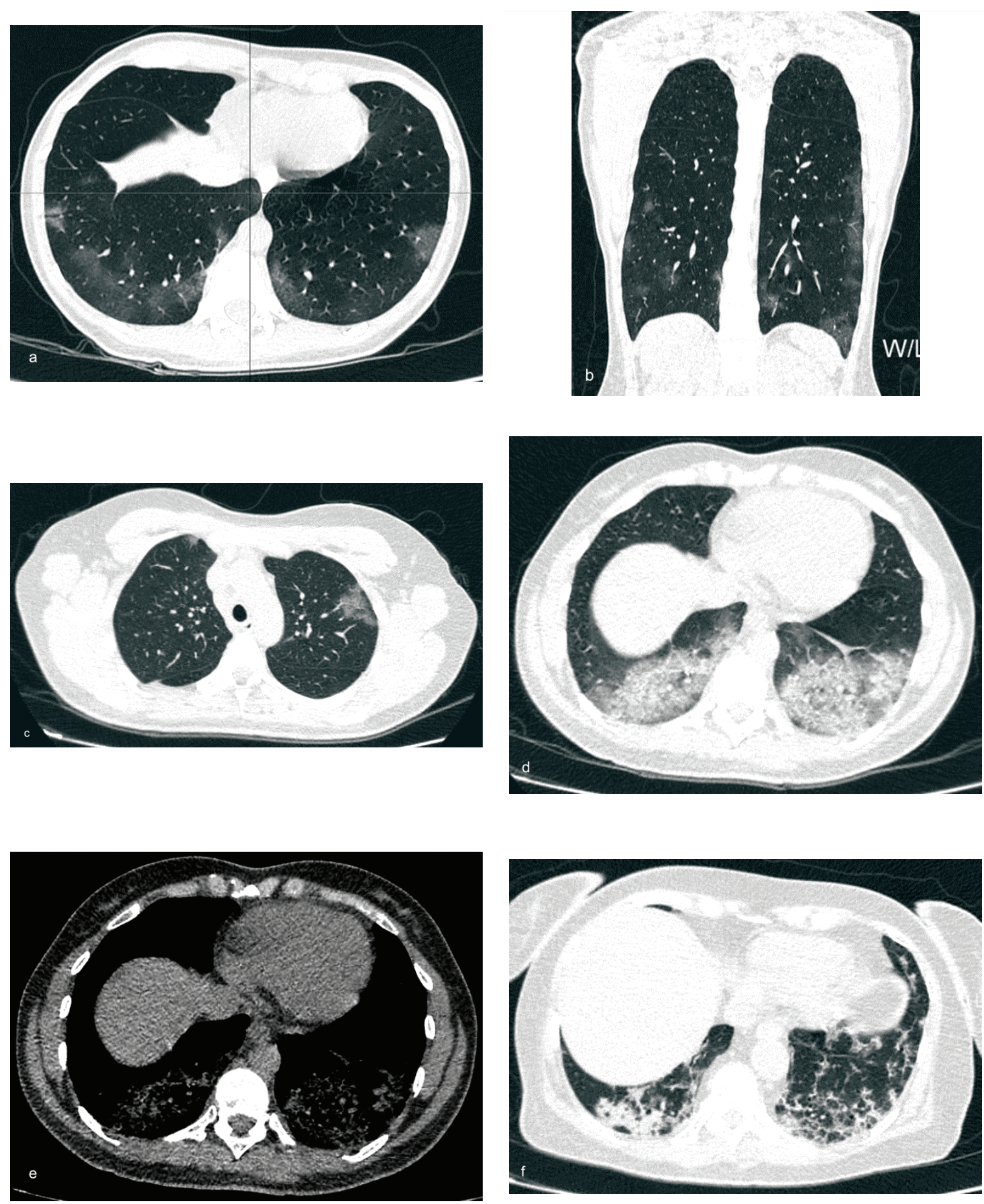

Slika 2. Tipična CT prezentacija i evolucija KOVID-19 pneumonije: bilateralne, multiple subpleuralno i periferno lokalizovane inflamatorne promene denziteta "mlečnog stakla" na poprečnom (a) i koronarnom preseku (b); znak „popločavanja“ (c); konsolidacija u pulmonalnom (d) i mekotkivnom „prozoru“ (e); organizujuća pneumonija (f)

Figure 2. Typical CT presentation and evolution of COVID-19 pneumonia: bilateral, multiple subpleural and peripherally localized ground-glass opacities in the axial (a) and coronal section (b); the 'paving-stone' sign (c); consolidation in the pulmonary (d) and soft tissue'window'(e); organizing pneumonia (f) 
Prema CT prezentaciji promena u plućima i vremenskoj dinamici njihove prezentacije, KOVID-19 pneumonija je podeljena u četiri stadijuma [4] (Tabela 1). Rani stadijum (stadijum intersticijumskog pneumonitisa) karakterišu promene denziteta "mlečnog stakla" (engl. GGO - ground glass opacities) (Slika 2a, 2b), koje nastaju kao posledica zapaljenske eksudacije $u$ intersticijum $[4,16]$. $U$ drugom, progresivnom stadijumu, vide se zadebljale intralobularne septe, usled zapaljenske proliferacije intersticijumskih elemenata, što povećava denzitet i daje sliku fine mreže unutar promena denziteta "mlečnog stakla“" (znak "popločavanja“; engl.'crazy paving' odnosno 'paving stone' sign) $[4,16]$ (Slika 2c). U trećem, stadijumu konsolidacije, koji predstavlja "pik"vrhunac pneumonije, denzitet se povećava do te mere da se unutar promena više ne razaznaju krvni sudovi $[4,16]$ (Slika 2d), može da se vidi vazdušni bronhogram, a konsolidacija se vidi i u „prozoru“ za vizualizaciju mekih tkiva, kao prisustvo tečnog sadržaja u acinusima pluća (Slika 2e). U četvrtom, stadijumu organizujuće pneumonije, dominiraju linearne i trakaste promene, (zadebljale interlobularne septe i fibroathezije), sa ostacima konsolidacije (Slika 2f).

Vrhunac rasprostranjenosti inflamatornih promena je u proseku oko 10. dana od pojave simptoma, a posle 14. dana se registruje postepena regresija njihovog broja i rasprostranjenosti [5] (Slika 3a, 3b). Kod pacijenata sa nepovoljnim kliničkim tokom, radiološka slika se pogoršava i posle 14. dana, sa pojavom novih slivenih zona denziteta "mlečnog stakla“, prelazeći u sliku akutnog respiratornog distres sindroma (ARDS), verovatno kao posledica generalizovanog pulmonalnog mikrovaskularnog opstruktivnog trombo-imflamatornog sindroma $[5,16]$.

\section{TYPES OF LUNG LESIONS AND THEIR EVOLUTION}

The types of lung lesions occurring in patients with mild or moderate clinical presentation, who have successfully recovered from COVID-19 pneumonia, as well as the evolution of these changes in the interval from symptom onset to recovery, were described in the studies by Pan et al., published online, on February 13, 2020 [4] and subsequently, in other numerous studies $[5,15,16]$.

Depending on the CT presentation of the lung changes and the dynamics of their presentation over time, COVID-19 pneumonia has been divided into four stages [4] (Table 1). The early stage (stage of interstitial pneumonitis) is characterized by lesions known as ground- glass opacities (GGO) (Figures 2a, 2b), which develop as the result of the release of inflammatory exudate into the interstitium $[4,16]$. In the second, progressive stage, thickened intralobular septs are visible, which occur due to the inflammatory proliferation of interstitial elements, which increases density and visually appears as a fine web within the ground-glass opacities ('crazy paving', i.e., 'paving stone' sign) $[4,16]$ (Figure 2c). In the third, the stage of consolidation, which represents the peak stage of pneumonia, the density is increased to such an extent that blood vessels cannot be distinguished within the changes in the lungs $[4,16]$ (Figure 2d), the air bronchogram sign is visible, and consolidation is also present in the soft tissue 'window', in the form of fluid content in the pulmonary acini (Figure 2e). In the fourth stage, i.e., the stage of organizing pneumonia, linear and band-like changes in the lungs are dominant (thickened interlobular septs and fibroadhesions), with remaining consolidation (Figure 2f).

The peak distribution of inflammatory changes in the lungs is, on average, on day 10 from the onset of

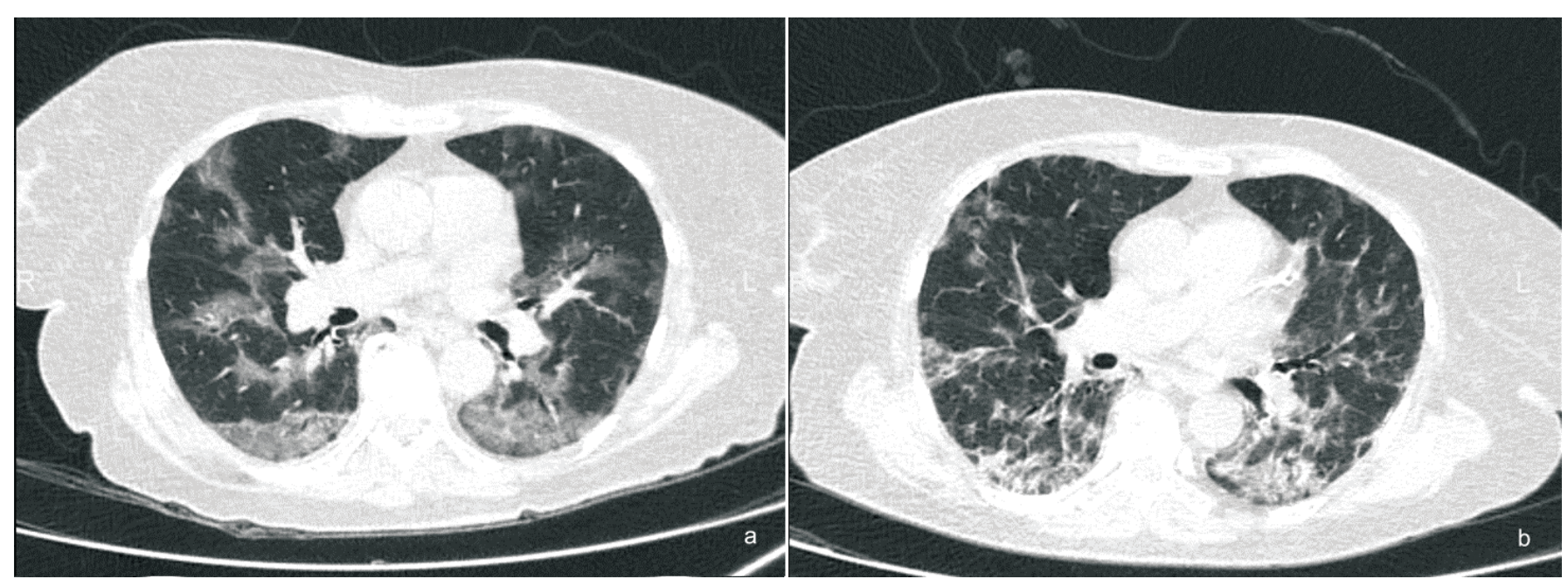

Slika 3. Evolucija KOVID-19 pneumonije kod šezdesetosmogodišnje pacijentkinje: uporedni prikaz (T nalaza, 11. dana („pik“) (a), i 29. dana od pojave simptoma (organizujuća pneumonija) (b)
Figure 3. Evolution of COVID-19 pneumonia in a 68-year-old female patient: a comparative presentation of (T findings on day 11 ('peak') (a), and day 29 of symptom onset (organizing pneumonia) (b) 
Kod asimptomatskih pacijenata i pacijenata sa blažom kliničkom slikom, tokom CT praćenja mogu da se vide samo promene denziteta "mlečnog stakla", a izostaje konsolidacija [16].

Fibrozne promene u plućima, kao kasne sekvele, detektovane su posle šest meseci kontrolnim CT pregledom u oko $35 \%$ bolesnika koji su bili hospitalizovani zbog KOVID-19 pneumonije [17].

\section{PROCENA VEROVATNOĆE KOVID-19 PNEUMONIJE U ODNOSU NA DRUGE UZROKE INTERSTICIJUMSKIH PNEUMONIJA}

Obostrane, multifokalne, kružne i slivene zone denziteta "mlečnog stakla“" (intersticijumski pneumonitis), a kasnije i konsolidacije, periferne/subpleuralne lokalizacije, najobimnije posteriorno $u$ donjim režnjevima, tipično se vizualizuju CT-om kod KOVID-19 pneumonije. Distribucija promena u plućima može biti lobularna (kružne zone), subpleuralna (slivene zone), ili difuzna [16].

Po pravilu, kod KOVID-19 pneumonije nisu prisutne ekskavacije/kavitacije i nodularne lezije u parenhimu pluća, kao ni uvećani medijastinalni limfni čvorovi, niti pleuralni izlivi $[12,18,19]$. Za procenu verovatnoće KOVID-19 pneumonije, na osnovu kriterijuma tipičnog/ atipičnog $\mathrm{CT}$ nalaza, i u cilju preciznije diferencijalne dijagnoze $u$ odnosu na intersticijumske pneumonije druge etiologije, predloženo je tri sistema gradiranja: RSNA (engl. Radiological Society of North America) [12], CO-RADS [18] i COVID-RADS [19], od kojih su prva dva našla širu kliničku primenu, bez značajne razlike u dijagnostičkoj pouzdanosti [20] (Tabela 2).

$U$ diferencijalnoj dijagnozi KOVID-19 pneumonije dolaze u obzir druge intersticijumske pneumonije različite etiologije, koje se karakteristično manifestuju promenama denziteta "mlečnog stakla“, kao što su: virusne (influenca tip A, adenovirus, hantavirus, respiratorni sincicijalni virus, SARS, MERS), atipične bakterijske pneumonije (mikoplazma, hlamidija), retka oportunistička gljivična Pneumocystis jiroveci pneumonija, hipersenzitivne, eozinofilne i lipoidne pneumonije, oštećenja pluća prouzrokovana upotrebom nekih lekova i narkotika, i dr. [21,22]. Poznavanje razlika u kliničkoj slici, laboratorijskim nalazima i tipičnoj radiološkoj prezentaciji, koju karakteriše predilekciono subpleuralna i perifrena distribucija inflamatornih promena u plućima, ključno je za postavljanje ispravne dijagnoze.

\section{SISTEMI BODOVANJA (SCORING) OBIMA I TEŽINE KOVID-19 PNEUMONIJE NA OSNOVU CT NALAZA I RADIOGRAFIJE}

Za procenu obima i težine pneumonije CT-om i radiografijom predloženi su različiti sistemi bodovanja (engl. scoring) od strane različitih autora [4,23-26]. symptoms, and after day 14 , gradual regression in their number and overall distribution can be registered [5] (Figures 3a, 3b). In patients with an unfavorable clinical course, the radiological finding worsens even after day 14 , with the development of new confluent ground-glass density zones, further progressing into the clinical presentation of acute respiratory distress syndrome (ARDS), probably as the result of generalized pulmonary microvascular obstructive thrombo-inflammatory syndrome $[5,16]$. In asymptomatic patients and patients with mild clinical presentation, CT monitoring shows only groundglass density opacities, and there is no consolidation [16]. Fibrous changes in the lungs, in the form of late sequelae, have been detected after a period of six months on follow-up CT examination, in approximately $35 \%$ of patients who were hospitalized due to COVID-19 pneumonia [17].

\section{ASSESSMENT OF THE PROBABILITY OF COVID-19 PNEUMONIA AS COMPARED TO OTHER CAUSES OF INTERSTITIAL PNEUMONIA}

Bilateral, multifocal, round and confluent zones of ground-glass density (interstitial pneumonitis), and subsequently also consolidations, localized peripherally/subpleurally, with the most extensive ones located posteriorly in the lower lobes, are typically visualized on CT examination in COVID-19 pneumonia. The distribution of pleural changes may be lobular (round zones), subpleural (confluent zones), or diffuse [16].

Typically, in COVID-19 pneumonia, there are no excavations/cavitations and nodular lesions in the pulmonary parenchyma, nor are there enlarged mediastinal lymph nodes or pleural effusion $[12,18,19]$. For the assessment of the probability of COVID-19 pneumonia, based on the typical/atypical CT scan criteria, and for the purpose of more precise differential diagnosis in relation to interstitial pneumonia of other etiology, three systems of grading have been proposed: RSNA (Radiological Society of North America) [12], CO-RADS [18] and COVID-RADS [19], of which the first two have come into wide clinical use, without significant difference in diagnostic reliability [20] (Table 2).

In the differential diagnosis of COVID-19 pneumonia, other types of interstitial pneumonia of various etiology are also a possibility, as they characteristically manifest with opacities of ground-glass density, as well. Among them are the following types of pneumonia: viral (type A influenza, adenovirus, hantavirus, respiratory syncytial virus, SARS, MERS), atypical bacterial pneumonia (mycoplasma, chlamydia), rare opportunistic fungal Pneumocystis jiroveci pneumonia, hypersensitive, eosinophilic and lipoid pneumonia, damage to the lungs caused by the use of some drugs and narcotics, etc. $[21,22]$. Knowing the differences in 
Tabela 2. Verovatnoća KOVID-19 pneumonije prema CT prezentaciji: RSNA i CORADS kriterijumi

\begin{tabular}{|ll}
\hline Kategorija & $\begin{array}{l}\text { Verovatnoća KOVID-19 } \\
\text { pneumonije }\end{array}$ \\
\hline Category & $\begin{array}{l}\text { Probability of COVID-19 } \\
\text { pneumonia }\end{array}$ \\
\hline & \\
Tipična & $\begin{array}{l}\text { Visoko specifična za KOVID-19 } \\
\text { pneumoniju }\end{array}$ \\
\hline
\end{tabular}
(znak „popločavanja") (znak „popločavanja”)
Table 2. Probability of COVID-19 pneumonia, based on CT presentation: RSNA and CO-RADS criteria

\begin{tabular}{lll}
\hline Kategorija & $\begin{array}{l}\text { Verovatnoća KOVID-19 } \\
\text { pneumonije }\end{array}$ & CT slika \\
\hline Category & $\begin{array}{l}\text { Probability of COVID-19 } \\
\text { pneumonia }\end{array}$ & CT image \\
\hline & RSNA* & \\
\hline
\end{tabular}

Periferne, bilateralne promene denziteta „mlečnog stakla“, sa ili bez konsolidacije ili vidljivih intralobularnih septi

Multifokalne kružne promene denziteta „,mlečnog stakla“ sa ili bez konsolidacije ili vidljivih intralobularnih septi

„Obrnuti halo" znak ili drugi znaci organizujuće pneumonije (vidljivi u kasnijem stadijumu bolesti)

Peripheral, bilateral ground- glass opacities, with or without consolidation or visible intralobular septs ('paving-stone'sign)

Typical Highly specific for COVID-19 Multifocal, round zones of ground-glass density with or without consolidation or visible intralobular septs ('pavingpneumonia stone'sign)

'Reversed halo' sign or other signs of organizing pneumonia (visible at a later stage of the disease)

Odsustvo tipičnih CT znakova i prisustvo:

Neodređena Nespecifična za KOVID-19 multifokalnih, difuznih, perihilarnih ili unilateralnih promena denziteta „,mlečnog stakla“, sa ili bez konsolidacije, nespecifičnog oblika i distribucije Nekoliko vrlo malih zona denziteta „mlečnog stakla“ koje nisu kružnog oblika niti periferne distribucije)

pneumoniju

Absence of typical CT signs and the presence of multifocal, diffuse, perihilar or unilateral ground-glass opacities, with or without consolidation, nonspecific in shape and distribution Several very small zones of ground-glass density, which are neither round nor peripherally distributed

pneumonia

Odsustvo tipičnih ili neodređenih znaka i prisustvo: izolovanih lobarnih ili segmentnih konsolidacija, bez promena

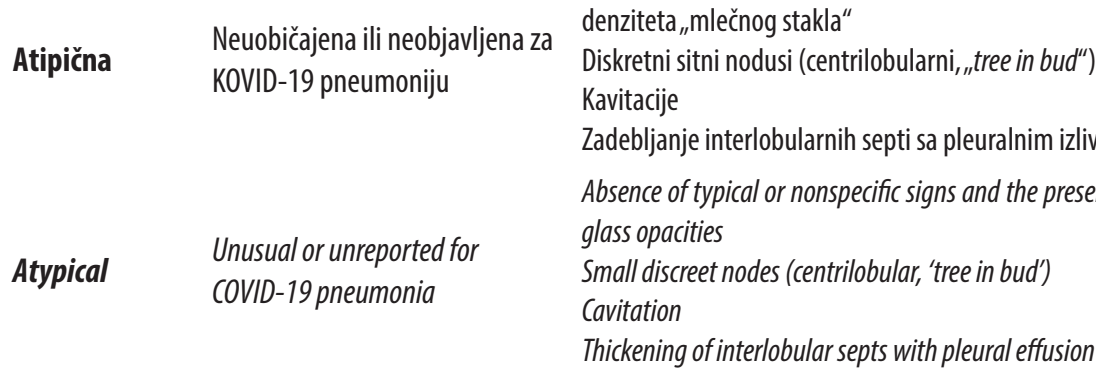

\section{CO-RADS**}

$\begin{array}{lll}\mathbf{0} & \text { Nije za interpretaciju } & \text { CT pregled insuficijentan za interpretaciju / } \\ \text { CT examination insufficient for interpretation }\end{array}$

$1 \quad$ Vrlo niska Normalan nalaz, ili odsustvo CT znaka infekcije /

2 Niska Tipičan CT nalaz za druge infekcije, ali ne za KOVID-19 pneumoniju /

$2 \quad$ Niska Typical CT finding for other infections, but not for COVID-19 pneumonia

$3 \quad$ Nesigurna

Promene kompatibilne sa oboljenjem KOVID-19 ali takođe prisutne i kod ostalih oboljenja / Changes compatible with the COVID-19 disease, but also present in other diseases

$4 \quad$ Visoka

Suspektna na KOVID-19/ Suspected of COVID-19

$5 \quad$ Vrlo visoka

Tipična za KOVID-19: promene denziteta „mlečnog stakla“, sa ili bez konsolidacije, u subpleuralnim delovima pluća i multifokalna bilateralna distribucija /

Typical for COVID-19: ground-glass opacities, with or without consolidation, in the subpleural regions of the lungs with multifocal bilateral distribution

$6 \quad$ Dokazana

Pozitivan PCR test na SARS-KoV-2/

Positive PCR test for SARS-COV-2

*RSNA: Radiological Society of North America Expert Consensus Statement on Reporting Chest CT Findings Related to COVID-19. Endorsed by the Society of Thoracic Radiology, the American College of Radiology, and RSNA [12]

**CO-RADS: COVID-19 Reporting and Data System developed by Dutch Radiological Society [18]
*RSNA: Radiological Society of North America Expert Consensus Statement on Reporting Chest CT Findings Related to COVID-19. Endorsed by the Society of Thoracic Radiology, the American College of Radiology, and RSNA [12]

**CO-RADS: COVID-19 Reporting and Data System developed by Dutch Radiological Society [18] 
Široko prihvaćen CT Severity Scoring System, koji je opisan u već pomenutoj studiji Pana i saradnika [4], na osnovu ranije korišćenog sistema bodovanja u analizi rasprostranjenosti promena u plućima kod ARDS-a, zasniva se na vizuelnoj, semikvantitativnoj proceni procentualne zahvaćenosti parenhima pluća zapaljenskim promenama. Na osnovu ovog sistema bodovanja, procenjuje se zahvaćenost svakog od pet lobusa pluća na skali od 0 do 5, pri čemu 1 bod podrazumeva da je inflamatornim promenama zahvaćeno manje od 5\% parenhima lobusa; 2 boda, da je zahvaćeno između $5 \%$ i 25\%; 3 boda, između 26 i 49\%; 4 boda, između 50-75\%; a 5 bodova da je upalom zahvaćeno više od $75 \%$ parenhima lobusa. Na taj način, ukupan broj bodova, tj. CT skor, može da se kreće od 0 do 25 [4] (Slika $4 a, 4 b)$. Druga grupa kineskih autora predložila je sličan, ali jednostavniji sistem bodovanja, sa skalom od 0 do 4, koja se od prethodnog razlikuje po tome što ne postoji kategorija zahvaćenosti do $5 \%$, nego 1 bod podrazumeva zahvaćenost do 25\% parenhima lobusa; 2 boda podrazumevaju zahvaćenost između $26 \%$ i $50 \%$; 3 boda ukazuju na zahvaćenost između 50\% i 75\%; dok 4 boda podrazumevaju zahvaćenost veću od 75\% [23]. Množenjem broja bodova sa pet (ukupan broj lobusa pluća) dobija se mogući raspon skora od 0 do 20 [23]. Složeniji sistemi bodovanja kombinuju procenu procentualne zahvaćenosti parenhima pluća, u segmentima ili lobusima, sa tipom zapaljenskih promena, pri čemu konsolidacija nosi dvostruko veći broj bodova u odnosu na promene denziteta "mlečnog stakla". Stoga se množenjem broja bodova za svaki plućni lobus i sabiranjem tih bodova dobijaju veće vrednosti ukupnog, kao i maksimalnog skora, u odnosu na dva prethodno navedena sistema bodovanja $[24,25]$.

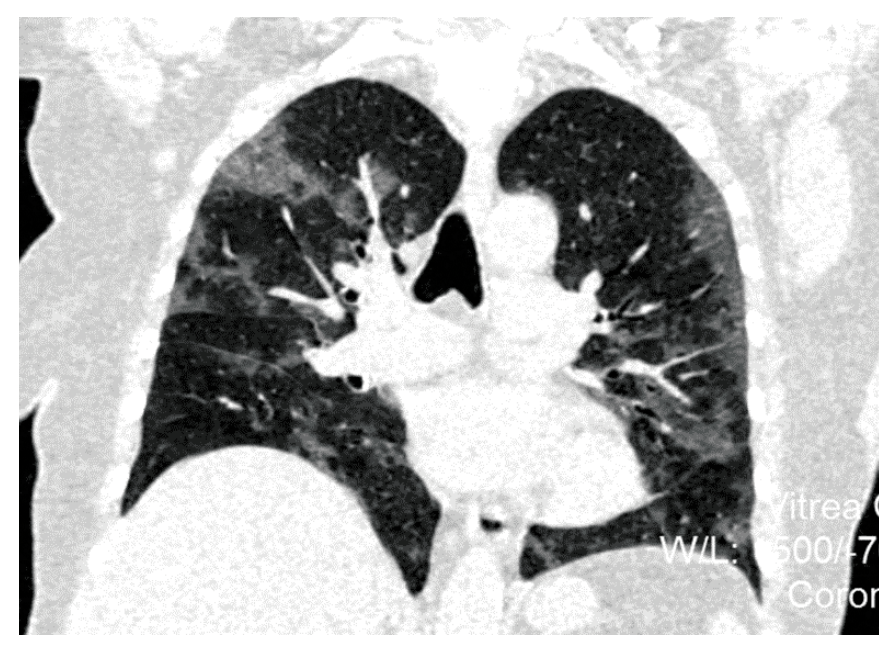

Slika 4. Koronarni (a) i sagitalni (b) presek CT pregleda iste pacijentkinje (aksijalni presek na slici 3a): u svim lobusima zahvaćeno $>25 \%$ parenhima (3 boda), stoga ukupan (T severity score procenjen na 15/25. the clinical presentation, the laboratory findings and the typical radiological presentation, characterized by predominantly subpleural and peripheral distribution of inflammatory changes in the lungs, is essential in establishing the right diagnosis.

\section{SCORING SYSTEMS FOR ASSESSING THE EXTENT AND SEVERITY OF COVID-19 PNEUMONIA ON THE BASIS OF CT AND RADIOGRAPHIC FINDINGS}

For the assessment of the extent and severity of pneumonia, based on CT and radiography findings, different scoring systems have been proposed by different authors [4,23-26]. The widely accepted CT Severity Scoring System, described in the above-mentioned study by Pan et al. [4], based on the previously applied scoring system for analyzing the scope of lung changes in ARDS, is founded on visual, semiquantitative assessment of the percentage of pulmonary parenchyma affected by inflammatory changes. Based on this scoring system, the extent of inflammation in each of the five lobes is assessed on a scale from 0 to 5 , with 1 point signifying that less than $5 \%$ of the lung parenchyma in the lobe is affected by inflammation; 2 points show that between $5 \%$ and $25 \%$ of the parenchyma is involved; 3 points indicate between $26 \%$ and $49 \%$ of parenchyma affected by inflammation; 4 points signify between $50 \%$ and $75 \%$ of parenchyma involved; while 5 points indicate that more than $75 \%$ of the parenchyma in the lobe is inflamed. Thus, the total number of points, i.e., CT score, can range from 0 to 25 [4] (Figures 4a, 4b). A different group of Chinese authors has proposed a similar, but simpler scoring system, with the scale ranging from 0 to 4 . It differs from the previous system in the fact that

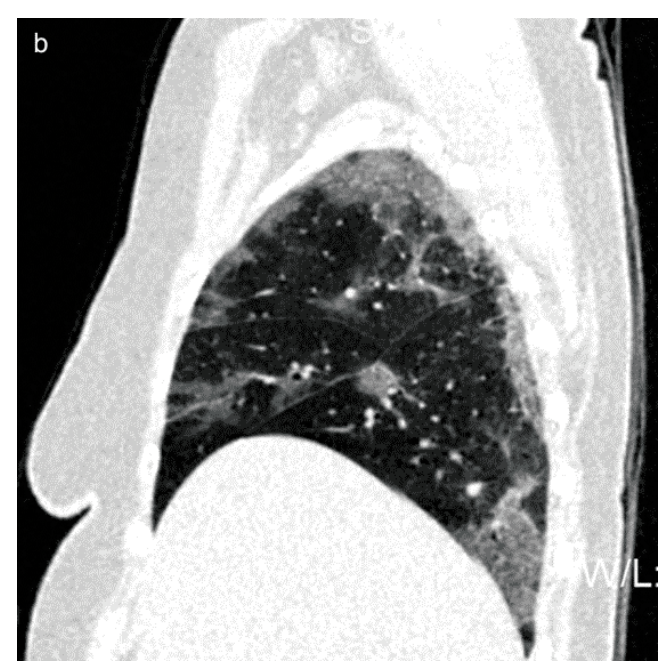

Figure 4. Coronal (a) and sagittal (b) section of the CT examination of the same patient (axial section in Figure 3a): in all lobes $>25 \%$ of parenchyma affected (3 points), therefore the total CT severity score estimated at 15/25 
Za procenu zahvaćenosti pluća na rendgenografiji takođe se koriste različiti načini bodovanja [26]. Najjednostavniji je onaj kojim se vizuelno procenjuje procenat zahvaćenosti svakog plućnog krila zapaljenskim promenama na skali od 1 do 4 (1:<25\%; 2: 25-50\%; 3: 26-75\%; i 4: $>75 \%)$, a zbir bodova za oba plućna krila može da se kreće u rasponu od 0 do 8 [26]. Italijanski autori iz Breše su publikovali CXR (engl. Chest X-Ray) ili Brixia sistem bodovanja kojim se analizira i dominantni tip zapaljenskih promena, a ne samo njihovo prisustvo [27]. Po ovoj klasifikaciji, oba plućna krila se dele na po tri plućna polja (gornje, srednje i donje), što čini ukupno 6 plućnih polja. U svakom se analizira prisustvo tri tipa zapaljenskih promena: intersticijumskih (1 bod), mešovitih intersticijumskih i konsolidacija ( 2 boda), i dominantno prisustvo konsolidacija (3 boda). Stoga, ukupan broj bodova može da se kreće u rasponu od 0 do 18 [27]. Sličan, ali jednostavniji princip, primenjen je u Chest Severity Score sistemu, koji su predložili američki autori, jer se analizira samo prisustvo zapaljenskih promena u svakom od tri plućna polja (gornje, srednje i donje), u oba plućna krila, pa je mogući raspon skora od 0 do 6 [28].

Za precizniju procenu procentualnog obima plućnog parenhima zahvaćenog pneumonijom može da se koristi CT volumetrija, kvantitativna metoda koja egzaktno pokazuje volumen parenhima pluća koji je zahvaćen zapaljenskim promenama, kao i volumen očuvanog parenhima pluća. Ova metoda može da bude manuelna, poluautomatska ili automatska, pri čemu su i brojni algoritmi zasnovani na primeni veštačke inteligencije takođe testirani i primenjuju se $[29,30]$. Pokazano je da zahvaćenost od više od oko $25 \%$ volumena parenhima pluća zapaljenskim promenama, vizualizovan CT-om, najčešće korelira sa respiratornom insuficijencijom, koja zahteva terapijsku primenu kiseonika [31]. Takođe je pokazano da su pacijenti sa težom kliničkom slikom i nepovoljnim ishodom inicijalno imali multilobularnu i difuznu distribuciju zapaljenskih promena, sa prosečno većim CT skorom, koji je nastavljao rapidno da raste sledećih nekoliko dana, prelazeći u ARDS $[24,32]$.

\section{ZAKLJUČAK}

Kompjuterizovanom tomografijom se sa visokom senzitivnošću detektuju inflamatorne promene u plućima kod pacijenata sa oboljenjem KOVID-19. Obostrane, multiple, kružne ili slivene zone denziteta "mlečnog stakla", predilekciono lokalizovane subpleuralno, periferno i posteriorno, obično najobimnije u donjim režnjevima, predstavljaju tipičnu CT prezentaciju KOVID-19 pneumonije. there is no category signifying less than $5 \%$ of parenchymal involvement, rather, 1 point signifies that up to $25 \%$ of the parenchyma of the lobe is affected; 2 points indicate between $26 \%$ and $50 \%$ of parenchyma involvement; 3 points signify that between $50 \%$ and $75 \%$ of parenchyma is affected; while 4 points indicate that more than $75 \%$ of the parenchyma in the lobe is inflamed [23]. By multiplying the number of points with five (total number of lung lobes), the overall score (possible range: 0 - 20) is obtained [23]. More complex scoring systems combine the assessment of the extent of parenchymal involvement, in the segments and the lobes, with the type of inflammatory changes, whereby consolidations carry double the number of points as compared to the ground-glass opacities. Therefore, by multiplying the number of points for each lung lobe and by adding these points up, higher values of the overall as well as the maximum score are obtained, as compared to the two previously described scoring systems [24,25].

Different scoring systems are also being used for assessing the extent of pulmonary parenchyma affected on X-ray images [26]. The simplest system is the one where the percentage to which each lung is affected by inflammatory changes is assessed visually on a scale ranging from 1 to $4(1:<25 \% ; 2: 25-50 \% ; 3: 26-75 \%$; and $4:>75 \%)$, and the sum of points for each lung can range from 0 to 8 [26]. Italian authors from Brescia have published the CXR (Chest X-Ray) or Brixia scoring system, which analyzes, not only the presence of inflammatory changes, but also their dominant type [27]. According to this classification, both lungs are divided into three fields each (upper, middle and lower), which makes a total of 6 lung fields. Each field is analyzed for the presence of three types of inflammatory changes: interstitial opacities (1 point), mixed interstitial and consolidation lesions ( 2 points), and dominant presence of consolidations ( 3 points). Thereby, the overall score cane range from 0 to 18 points [27]. A similar, but simpler method is applied in the Chest Severity Score System, proposed by American authors, as it analyzes only the presence of inflammatory changes in each of the three fields of the lungs (upper, middle and lower), in both lungs. Therefore, the possible score range is between 0 and 6 [28].

For a more precise assessment of the percentage of the lung parenchyma affected by pneumonia, volumetric CT analysis, a quantitative method which exactly shows the volume of lung parenchyma affected by inflammatory changes, as well as the volume of unaffected parenchyma, may be applied. This method can be manual, semiautomatic or automatic, while numerous algorithms based on the application of artificial intelligence have also been tested and applied $[29,30]$. It has been shown that the extent of lung pa- 
Ponavljanim niskodoznim CT pregledima moguće je pratiti dinamiku evolucije pneumonije u kvalitativnom (stadijum) i kvantitativnom (obim zahvaćenosti pluća inflamatornim promenama) smislu. Radiografija pluća, iako manje senzitivna od CT, zbog masovne dostupnosti, jednostavnijeg, kratkotrajnijeg i bezbednijeg izvođenja i manje eksponencijalne doze zračenja za pacijenta, ostaje široko zastupljena u trijaži i praćenju pacijenata sa oboljenjem KOVID-19.

Sukob interesa: Nije prijavljen.

\section{LITERATURA / REFERENCES}

1. Huang C, Wang Y, Li X, Ren L, Zhao J, Hu Y, et al. Clinical features of patients infected with 2019 novel coronavirus in Wuhan, China. Lancet. 2020;395(10223):497-506.

2. Chan JF, Yuan S, Kok KH, To KK, Chu H, Yang J, et al. A familial cluster of pneumonia associated with the 2019 novel coronavirus indicating person-to-person transmission: a study of a family cluster. Lancet. 2020;395(10223):514-23.

3. Zhu N, Zhang D, Wang W, Li X, Yang B, Song J, et al. China Novel Coronavirus investigating and research team. A Novel Coronavirus from patients with pneumonia in China, 2019. N Engl J Med. 2020;382(8):727-33.

4. Pan F, Ye T, Sun P, Gui S, Liang B, Li L, et al. Time Course of Lung Changes at Chest CT during Recovery from Coronavirus Disease 2019 (COVID-19). Radiology. 2020;295(3):715-21.

5. Salehi S, Abedi A, Balakrishnan S, Gholamrezanezhad A. Coronavirus Disease 2019 (COVID-19): A systematic review of imaging findings in 919 patients. AJR Am J Roentgenol. 2020;215(1):87-93.

6. Ai T, Yang Z, Hou H, Zhan C, Chen C, Lv W, et al. Correlation of chest CT and RT-PCR testing in Coronavirus Disease 2019 (COVID-19) in China: A report of 1014 cases. Radiology. 2020;296(2):E32-40.

7. Xie X, Zhong Z, Zhao W, Zheng C, Wang F, Liu J. Chest CT for typical 2019nCoV pneumonia: Relationship to negative RT-PCR Testing. Radiology. 2020;296(2):E41-5.

8. Inui S, Fujikawa A, Jitsu M, Kunishima N, Watanabe S, Suzuki Y, et al. Chest CT findings in cases from the cruise ship Diamond Princess with Coronavirus Disease (COVID-19). Radiol Cardiothorac Imaging. 2020;2(2):e200110. renchyma involvement, as seen on the $\mathrm{CT}$ scan, which exceeds $25 \%$ of the overall parenchyma volume, correlates most commonly with respiratory insufficiency, which requires oxygen therapy [31]. It has also been demonstrated that patients with more severe clinical presentation and a less favorable outcome, initially had multilobular and diffuse distribution of inflammatory lesions, with a higher average CT score, which continued to rapidly rise in the several following days, turning into ARDS [24,32].

\section{CONCLUSION}

Computed tomography detects, with high sensitivity, inflammatory changes in patients with COVID-19. Bilateral, multiple, round or confluent zones of groundglass density, predominantly localized subpleurally, peripherally and posteriorly, usually most extensive in the lower lobes, represent a typical CT presentation of COVID-19 pneumonia.

Repeated low-dose CT scan examinations make it possible to monitor the dynamics of the evolution of pneumonia in the qualitative (stage) and quantitative (extent of the inflammation in the lungs) sense. Chest radiography, although less sensitive than $C T$, due to wide availability, simpler, shorter and safer application, as well as a lower exponential dose of radiation for the patient, remains widely applied in triage and follow-up of COVID-19 patients.

Conflict of interest: None declared.

9. Rubin GD, Ryerson CJ, Haramati LB, Sverzellati N, Kanne JP, Raoof S, et al. The Role of chest imaging in patient management during the COVID-19 pandemic: A multinational consensus statement from the Fleischner Society. Radiology. 2020;296(1):172-80.

10. Wong HYF, Lam HYS, Fong AH, Leung ST, Chin TW, Lo CSY, et al. Frequency and distribution of chest radiographic findings in COVID-19 positive patients. Radiology. 2020;296(2):E72-8.

11. Vespro V, Andrisani MC, Fusco S, Di Meglio L, Plensich G, Scarabelli A, et al. Chest X-ray findings in a large cohort of 1117 patients with SARS-CoV-2 infection: a multicenter study during COVID-19 outbreak in Italy. Intern Emerg Med. 2021; 16(5):1173-81.

12. Simpson S, Kay FU, Abbara S, Bhalla S, Chung JH, Chung M, et al. Radiological Society of North America Expert consensus statement on reporting chest CT findings related to COVID-19. Endorsed by the Society of Thoracic Radiology, the American College of Radiology, and RSNA - Secondary Publication. J Thorac Imaging. 2020;35(4):219-27.

13. Kang Z, Li X, Zhou S. Recommendation of low-dose CT in the detection and management of COVID-2019. Eur Radiol 2020; 30(8):4356-7.

14. Léonard-Lorant I, Delabranche X, Séverac F, Helms J, Pauzet C, Collange 0, et al. Acute pulmonary embolism in patients with COVID-19 at CT angiography and relationship to d-dimer levels. Radiology. 2020;296(3):E189-91.

15. Wang YC, Luo H, Liu S, Huang S, Zhou Z, Yu Q, et al. Dynamic evolution of COVID-19 on chest computed tomography: experience from Jiangsu Province of China. Eur Radiol. 2020;30(11):6194-203. 
16. Wu J, Pan J, Teng D, Xu X, Feng J, Chen Y-C. Interpretation of CT signs of 2019 novel coronavirus (COVID-19) pneumonia. Eur Radiol. 2020;30(10):5455-62.

17. Han X, Fan Y, Alwalid 0, Li N, JiaX, Yuan M, etal. Six-monthfollow-up chest CT findings after severe COVID-19 pneumonia. Radiology. 2021;299(1):E177-86.

18. Prokop M, van Everdingen W, van Rees Vellinga T, Quarles van Ufford $H$, Stöger L, Beenen L, et al. COVID-19 standardized reporting working group of the Dutch Radiological Society. CO-RADS: A categorical CT assessment scheme for patients suspected of having COVID-19-Definition and evaluation. Radiology. 2020;296(2):E97-104.

19. Salehi S, Abedi A, Balakrishnan S, Gholamrezanezhad A. Coronavirus disease 2019 (COVID-19) imaging reporting and data system (COVID-RADS) and common lexicon: a proposal based on the imaging data of 37 studies. Eur Radiol. 2020;30(9):4930-42.

20. Abdel-Tawab M, Basha MAA, Mohamed IAI, Ibrahim HM, Zaitoun MMA, Elsayed SB, et al. Comparison of the CO-RADS and the RSNA chest CT classification system concerning sensitivity and reliability for the diagnosis of COVID-19 pneumonia. Insights Imaging. 2021;12(1):55.

21. Guarnera A,Podda P, SantiniE,Paolantonio P, Laghi A. Differential diagnoses of COVID-19pneumonia:thecurrentchallengefortheradiologist-apictorialessay. Insights Imaging. 2021;12(1):34.

22. Hani C, Trieu NH, Saab I, Dangeard S, Bennani S, Chassagnon G, et al. COVID-19 pneumonia: A review of typical CT findings and differential diagnosis. Diagn Interv Imaging. 2020;101(5):263-8.

23. Chung M, Bernheim $A$, Mei X, Zhang N, Huang M, Zeng X, et al. CT imaging features of 2019 Novel Coronavirus (2019-nCoV). Radiology. 2020;295(1):202-7.
24. Li Y, Yang Z, Ai T, Wu S, Xia L. Association of "initial CT" findings with mortality in older patients with coronavirus disease 2019 (COVID-19) Eur Radiol. 2020;30(11):6186-93.

25. Yang R, Li X, Liu H, Zhen Y, Zhang X, Xiong $Q$, et al. Chest CT severity score: An imaging tool for assessing severe COVID-19. Radiol Cardiothorac Imaging. 2020;2(2):e200047.

26. Wasilewski PG, Mruk B, Mazur S, Półtorak-Szymczak G, Sklinda K, Walecki J. COVID-19 severity scoring systems in radiological imaging - a review. Pol J Radiol. 2020;85:e361-8.

27. Borghesi A, Maroldi R. COVID-19 outbreak in Italy: experimental chest X-ray scoring system for quantifying and monitoring disease progression. Radiol Med. 2020;125(5):509-13.

28. Toussie D, Voutsinas N, Finkelstein M, Cedillo MA, Manna S, Maron SZ, et al. Clinical and chest radiography features determine patient outcomes in young and middle-aged adults with COVID-19. Radiology. 2020;297(1):E197-E206.

29. Lanza E, Muglia R, Bolengo I, Santonocito OG, Lisi C, Angelotti G, et al. Quantitative chest CT analysis in COVID-19 to predict the need for oxygenation support and intubation. Eur Radiol. 2020;30(12):6770-8.

30. Näppi J, Uemura T, Watari C, Hironaka T, Kamiya T, Yoshida H. U-survival for prognostic prediction of disease progression and mortality of patients with COVID-19. Sci Rep. 2021;11(1):9263.

31. Colombi D, Bodini FC, Petrini M, Maffi G, Morelli N, Milanese G, et al. Well-aerated Lung on Admitting Chest CT to Predict Adverse Outcome in COVID-19 Pneumonia. Radiology. 2020;296(2):E86-96.

32. Pan F, Zheng C, Ye T, Li L, Liu D, Li L, et al. Different computed tomography patterns of Coronavirus Disease 2019 (COVID-19) between survivors and non-survivors. Sci Rep. 2020;10(1):11336. 